\title{
Investigation of Brucellosis Using Molecular and Serological Tools in Selected Sites of Maekel Region, Eritrea
}

\author{
Bereket Mihreteab Weldegiorgis, Araia Berhane Mesfin, Negassi Leake Beyene, \\ Yodahi Petros Afewerki, Munir Wehab Abdelkadr, Tekeste Okubamichael Tsegai, \\ Fitsum Neguse Nuwayu, and Zenawi Zeramariam Araia
}

\section{ABSTRACT}

Brucellosis is a zoonotic disease primarily affecting animals and accidentally exposed humans. In Eritrea, brucellosis endemicity is proven by several sero-prevalence studies in domestic animals and occupationally exposed humans. However, there is a gap of information on the commonly occurring brucella species and cause of human/animal brucellosis. The objective of this study is to identify brucella species in sheep and goats which possibly pose risk to human brucellosis. Out of a total 71 serum and 71 vaginal swab samples collected from sheep and goats, eight serum samples by Rose Bengal plate test (RBPT) and 4 vaginal swabs by polymerase chain reaction (PCR) were found positive for brucellosis. Combinatorial PCR detected Br. melitensis from the four PCR positive samples. Questionnaire interviews collected from 68 confirmed brucellosis patients showed that habits of drinking unpasteurized yoghurt and raw milk and handling of aborted materials were common. This investigation study suggests, $\mathrm{Br}$. melitensis could be the major cause of brucellosis in humans and animals in Maekel region Eritrea. Therefore, a large-scale epidemiological study is recommended to confirm the true extent of the problem in animals and humans.

Keywords: Maekel region, Polymerase chain reaction (PCR), Brucella melitensis, Rose Bengal Plate Test (RBPT).

Published Online: June 30, 2021

ISSN: 2684-5199

DOI: $10.24018 /$ ejbio.2021.2.3.189

Bereket Mihreteab Weldegiorgis*

National Animal and Plant Health Laboratory, Ministry of Agriculture, Asmara, Eritrea.

(e-mail: bere.assvet@gmail.com )

Araia Berhane Mesfin

Communicable Disease Control Division, Ministry of Health, Asmara, Eritrea.

Negassi Leake Beyene

Orotta College of Medicine and Health Sciences, Ministry of Health, Asmara, Eritrea.

Yodahi Petros Afewerki

National Animal and Plant Health Laboratory, Ministry of Agriculture, Asmara, Eritrea.

Munir Wehab Abdelkadr

National Animal and Plant Health

Laboratory, Ministry of Agriculture,

Asmara, Eritrea.

Tekeste Okubamichael Tsegai

National Animal and Plant Health Laboratory, Ministry of Agriculture, Asmara, Eritrea.

Fitsum Neguse Nuwayu

National Animal and Plant Health Laboratory, Ministry of Agriculture, Asmara, Eritrea.

Zenawi Zeramariam Araia

Communicable Disease Control

Division, Ministry of Health, Asmara, Eritrea.

*Corresponding Author

\section{INTRODUCTION}

Brucellosis is an infectious disease primarily affecting domestic and wild animals; however, it is incidentally or accidentally transmitted to humans and has serious implications. Brucellosis is caused by gram negative coccobacilli, small, non-motile, strict intracellular bacteria of the genus brucella. Based on DNA homology studies, the genus brucella represents a single species. However, for epidemiological and diagnostic benefits, brucella has been classified in to 12 species called Brucella melitensis, Br. abortus, Br. ovis, Br. suis, Br. canis, Br. neotomae, Br.microti, Br. ceti, Br. pinnipedialis, Br. inopinata, Br. papionis, Br.vulpis [1], [2]. Br.melitensis, Br.abortus and Br.suis are considered the most pathogenic species for humans, and have small ruminants, cattle and pigs as preferential hosts, respectively [3]. Most severe clinical and pathologic effects are known to be caused by $\mathrm{Br}$. melitensis in humans and it can pose a great risk for people living in close proximity to small ruminants.

In animals, brucellosis predominantly affects the reproductive system inducing abortions, stillbirth, and 
infertility [4]. Human brucellosis is mostly characterized by fever, arthralgia, myalgia, and back pain [5]. As $78 \%$ patients with brucellosis suffer from fever, it is frequently misdiagnosed as other febrile diseases, such as malaria and creates a diagnostic challenge in endemic countries. Brucellosis is considered a major public health problem and burden to economy, with regard to the symptoms and health complications produced in humans and reduced milk production and infertility in animals.

Brucella diagnosis is based on direct diagnostic methods involving microbiological analysis or DNA detection by polymerase chain reaction (PCR) and indirect serological tests. Isolation by culture media and biochemical characterization is the gold standard method [1]. However, isolation is time and resource intensive and requires highly skilled technical personnel to handle samples and live bacteria for eventual identification and bio typing [6]. Molecular methods, application of PCR is useful depending on their improved sensitivity, specificity, and simplicity. Initially PCR based methods were developed on bacterial isolates and are now also used on clinical samples from humans and animals [7].

In Eritrea, brucellosis endemicity in humans and animals is indicated by several sero-prevalence studies [8]-[10]. Moreover, animal brucellosis in sheep and goats was evident in the pastoralist areas of eastern and western lowlands [10]. Reports on the incidence of human brucellosis have been showing significant increment in the last years from all over the country (NAPHL, unpublished data). Diagnosis of brucellosis in humans and animals is serological by Rose Bengal plate test (RBPT), complement fixation test (CFT) and enzyme linked immune-sorbent assay (ELISA). Use of confirmatory techniques such as bacteria isolation and molecular methods are underutilized and not reported in previous studies. Uses of microbiological analysis and DNA detection have the additional advantage of identifying brucella species and biovars. There is a gap of information on the prevailing brucella species involved in animal/human brucellosis, which is particularly useful for epidemiological trace back or for species specific eradication programs [9, 11]. Hence the objective of this study is investigating brucella species from sheep and goats living in a household of brucella infected human cases.

\section{METHODS}

\section{A. Study Area}

The targeted study areas are Shimanugus, Gulie, Tredishi, Himbirti and Abardae (Fig. 2) villages located in central region of Eritrea (Zoba Maekel) (Fig. 1). The study area was chosen in response to the reported number of brucella cases in humans to the National Animal and Plant Health Laboratory (NAPHL). The economy of these populations depends on agricultural activities, and they practice sedentary mixed crop and livestock rearing, which includes sheep, goat, and a few cattle.

\section{B. Study Design and Sampling Procedure}

The study is cross-sectional and descriptive in sheep and goats living in close proximity to brucellosis infected individuals. Purposive sampling was applied to identify cases of brucellosis from these villages for data and sample collection referring the admission logbook of the NAPHL. Subsequently, selection criteria were designed to choose households with one or more brucellosis infected human members, owning small ruminants and accessible by transport. In the five villages 32 households were eligible for inclusion in the study. Animals, from existing ewes and does in the households, previously aborted or after birth in less than 3 weeks were included in the study.

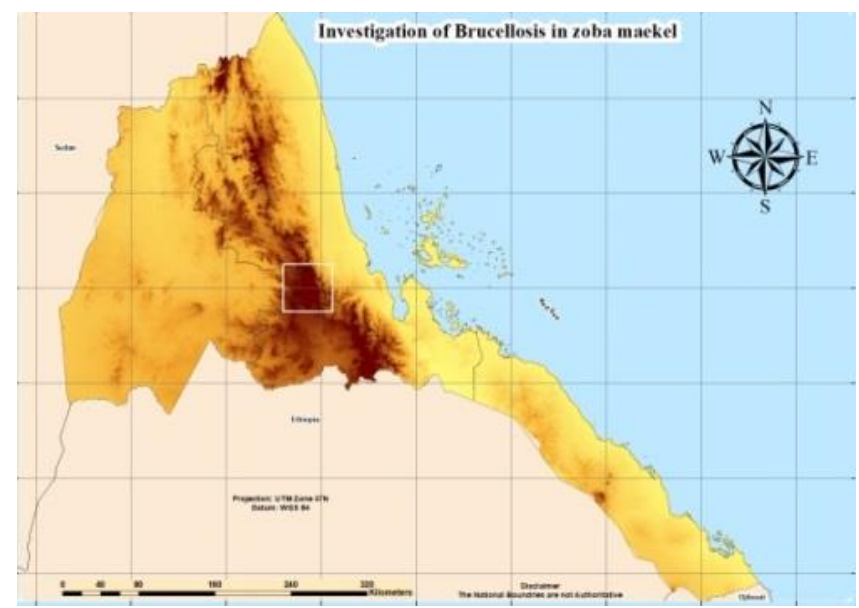

Fig. 1. Geographical location of Maekel region.

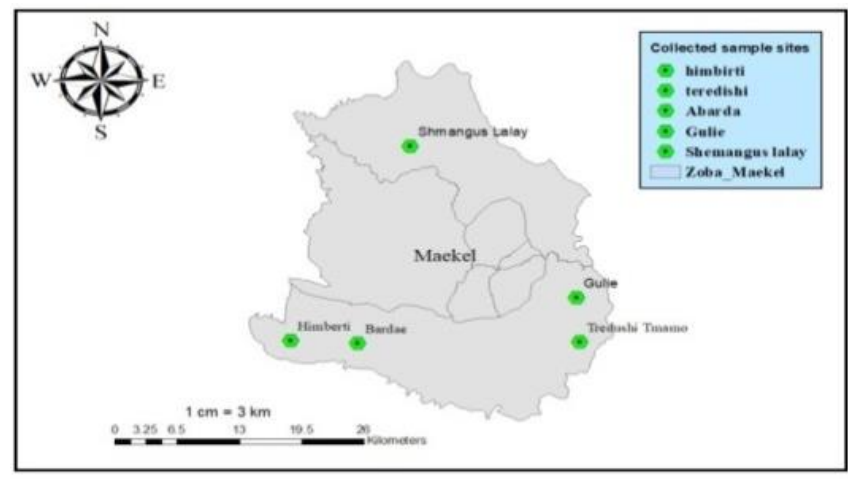

Fig. 2. Sampled villages in Maekel region.

\section{Data Collection and Analysis}

Data was collected using structured questionnaire adopted from Omer et al 2002, that included demographic characteristics such as age, sex, occupation, types of animals owned, consumption of unpasteurized milk and milk products, handling of calving/abortions and clinical signs exhibited [9]. The aims and importance of the study were explained to all participants and informed consent received before data and sample collection.

Data and laboratory results were stored in Microsoft excel and transferred to SPSS IBM version 23 software for analysis. Descriptive statistics, i.e., frequency and percentage were used to summarize the data collected.

\section{Laboratory Procedure}

\section{Sample collection}

From each animal serum and vaginal swab samples were collected. All samples were transported to NAPHL through cold chain and stored at $-20{ }^{\circ} \mathrm{C}$ until processed by RoseBengal plate test (RBPT) and polymerase chain reaction (PCR). There was no vaccination against animal brucellosis, 
and thus all sampled animals were unvaccinated.

\section{Serological test}

Rose Bengal Plate test (RBPT) was applied for the detection of brucella antibodies in serum samples from humans and animals. The method performed according to Alton et al. 1988 [12]. Brucella abortus Strain 99 antigen and standard positive and negative reference bovine control sera derived from Weybridge, Animal Health and Veterinary Agency, UK, were included for assay validation.

\section{Sample processing and DNA extraction}

Vaginal swabs were taken by sterile swabs, put in sterile cold phosphate buffered saline (PBS) and contained in screw capped glass containers. These swabs were kept for 24 hours at $4{ }^{\circ} \mathrm{C}$, before being vortexed and squeezed in the wall of the tubes and discarded. In the laboratory, the swab suspensions were briefly centrifuged at $4000 \mathrm{rpm}$ for 10 minutes to concentrate the agent in the sediment. Subsequently, the supernatant was discarded, leaving $1 \mathrm{ml}$ fluid with the sediment to be used for extraction. DNA extraction was performed using QIAamp DNA mini kit, by adding $200 \mu \mathrm{l}$ of sample with $200 \mu \mathrm{l}$ buffer AL and $20 \mu \mathrm{l}$ Proteinase $\mathrm{K}$ and briefly incubated at $56^{\circ} \mathrm{C}$ for 10 minutes. The samples were then washed, centrifuged, and eluted following the protocol provided by Qiagen.

\section{Molecular detection (PCR)}

Polymerase chain reaction (PCR) was performed by two separate steps. First step was brucella genus detection using general primers B4 (TGG CTG GGT TGC CAA TAT CAA) and B5 (CGC GCT TGC CTT TCA GGT CTG) as described by Baily et al 1992[13]. Master Mix was prepared using DreamTaq, Thermo scientific kit according to manufacturer's protocol. The total volume of the reaction mixture was $25 \mu \mathrm{l}$ : $12.5 \mu \mathrm{l}$ of readymade PCR mix, $8.5 \mu \mathrm{l}$ of nuclease free water, $0.5 \mu \mathrm{l}(0.2 \mu \mathrm{M})$ each of B4 and B5 primers, and $3 \mu 1$ of DNA sample. The amplification program was set in Thermal cycler (Master cycler, eppendorf) at $94{ }^{\circ} \mathrm{C}$ for $5 \mathrm{~min}$ initial denaturation followed by 35 cycles of denaturation at $94^{\circ} \mathrm{C}$ for $45 \mathrm{secs}$, annealing at $60^{\circ} \mathrm{C}$ for $1 \mathrm{~min}$ and extension at $72{ }^{\circ} \mathrm{C}$ for $1 \mathrm{~min}$, followed by a final extension at $72{ }^{\circ} \mathrm{C}$ for $5 \mathrm{~min}$. The second step PCR, was species specific assay for the differentiation and identification of two Brucella species using duplex PCR, following modification of the original protocol by Bricker and Halling [14]. This reaction was made by 3 primer pairs, in which one primer pair anneals to a target gene IS711, while the other two primers anneal to either Brucella aborus or melitensis genes. The type and concentration of primers, amplified product size and cycling conditions are explained in Table I. The master mix was prepared according to manufacturer's protocol using Dream Taq readymade PCR kit and $3 \mu \mathrm{l}$ sample extract added to a final volume of $25 \mu \mathrm{l}$. Amplified products were visualized through gel electrophoresis. The gel was prepared by $(1.5 \%$ $\mathrm{w} / \mathrm{v}$ ) in $1 \times \mathrm{TAE}$ (Tris acetate EDTA) buffer and stained with Gel red DNA dye. The gel electrophoresed for 60 minutes at 100v. The size of DNA fragments compared with $100 \mathrm{bp}$ DNA ladder/ $1 \mathrm{~kb}$ plus DNA ladder. Finally, the gel was observed under UV light for positive bands and result recording.
TABLE I: CyCLING PROGRAM AND PRIMERS USED FOR DUPLEX PCR

\begin{tabular}{|c|c|c|c|c|c|}
\hline Primer sequence & $\begin{array}{l}\text { Final } \\
\text { conc. }\end{array}$ & $\begin{array}{l}\text { Amplicon } \\
\text { size }\end{array}$ & \multicolumn{3}{|c|}{ Amplification program } \\
\hline $\begin{array}{c}\text { IS711:TGCCGAT } \\
\text { CACTTAAGGG } \\
\text { CСТTCAT }\end{array}$ & $0.4 \mu \mathrm{M}$ & & $\begin{array}{r}\text { In } \\
\text { denat }\end{array}$ & $\begin{array}{l}\text { ial } \\
\text { ration }\end{array}$ & $\begin{array}{c}95^{\circ} \mathrm{C} \text { for } \\
5 \mathrm{~min}\end{array}$ \\
\hline $\begin{array}{c}\text { MEL:AAATCGC } \\
\text { GTCCTTGCTGG } \\
\text { TCTGA }\end{array}$ & $0.2 \mu \mathrm{M}$ & $731 \mathrm{bp}$ & Ext. & $\begin{array}{c}95^{\circ} \mathrm{C} \\
\text { for } 1 \\
\min \\
55.5^{\circ} \mathrm{C} \\
\text { for } 2 \\
\min \\
72^{\circ} \mathrm{C} \\
\text { for } 2 \\
\min \end{array}$ & $\begin{array}{c}35 \\
\text { cycles }\end{array}$ \\
\hline $\begin{array}{c}\text { AB: } \\
\text { GACGAACGC } \\
\text { AATTTTTCCAA } \\
\text { TCCC }\end{array}$ & $0.2 \mu \mathrm{M}$ & $498 \mathrm{bp}$ & $\begin{array}{r}\mathrm{Fi} \\
\text { exter }\end{array}$ & & $\begin{array}{c}72^{\circ} \mathrm{C} \text { for } 7 \\
\min \end{array}$ \\
\hline
\end{tabular}

\section{RESULTS}

\section{A. Background Characteristics}

In total 32 households were visited and 68 individuals from these were interviewed. According to Table II, most frequent age of the infected patients was from 11-30 years, and males were predominant than females. In addition, $75 \%$ of the occupation was dominated by agro-pastoralists (involved in both faming and herding activities).

TABLE II: PATIENT'S BACKGROUND CHARACTERISTICS

\begin{tabular}{|c|c|c|c|}
\hline Variable & Group & $\begin{array}{l}\text { Number of } \\
\text { patients }\end{array}$ & $\begin{array}{l}\text { Percentage } \\
\qquad(\%)\end{array}$ \\
\hline \multirow{5}{*}{ Age } & $<10$ years & 3 & 4 \\
\hline & $11-30$ years & 33 & 49 \\
\hline & $31-50$ years & 16 & 23 \\
\hline & $51-70$ years & 12 & 18 \\
\hline & $71-90$ years & 4 & 6 \\
\hline \multirow{3}{*}{ Sex } & Male & 50 & 73 \\
\hline & Female & 18 & 27 \\
\hline & Student & 14 & 20 \\
\hline \multirow{4}{*}{ Occupation } & Agro-pastoralist & 51 & 75 \\
\hline & Soldier & 2 & 3 \\
\hline & Butcher & 1 & 2 \\
\hline & Milk & 12 & 17 \\
\hline \multirow{4}{*}{$\begin{array}{l}\text { Consumption of raw } \\
\text { animal products }\end{array}$} & Meat & 2 & 3 \\
\hline & Yoghurt & 27 & 40 \\
\hline & Milk and yoghurt & 14 & 20 \\
\hline & Not taken & 13 & 19 \\
\hline \multirow{5}{*}{$\begin{array}{c}\text { Ever assisted animals } \\
\text { at birth or handled } \\
\text { aborted material }\end{array}$} & Yes & 55 & 82 \\
\hline & No & 13 & 18 \\
\hline & Goats & 5 & 7 \\
\hline & Sheep & 21 & 32 \\
\hline & Sheep and goats & 5 & 7 \\
\hline \multirow{5}{*}{$\begin{array}{c}\text { Types of animals } \\
\text { owned }\end{array}$} & $\begin{array}{c}\text { Sheep, goats, and } \\
\text { cows }\end{array}$ & 8 & 12 \\
\hline & Sheep and cows & 6 & 9 \\
\hline & Goat and cows & 10 & 15 \\
\hline & Cows & 11 & 16 \\
\hline & No contact & 2 & 2 \\
\hline
\end{tabular}

History of consumption of raw meat, unpasteurized milk and yoghurt from different animals indicated that $27(40 \%)$ had history of taking unpasteurized yoghurt, 12 (17\%) a habit of drinking milk, $14(20 \%)$ milk and yoghurt consumption and $2(3 \%)$ eating raw meat. Majority $(82 \%)$ of the respondents confirmed assisting animals at birth or handling 
aborted materials. On the bases of animal types owned; $21(32 \%)$ raise sheep, $5(7 \%)$ raise goats, 11 (16\%) own cows and the rest owns mixed species of sheep, goats, and cows. And 2 individuals had no animals of their own and no history of contact with animals.

Fever was a predominant symptom (51/68), among the patients diagnosed for brucellosis followed by arthralgia (45/68), fatigue (43/68), headache (41/68), night sweats $(37 / 68)$ and low back pain $(37 / 68)$ (Table III).

\begin{tabular}{cc}
\multicolumn{2}{c}{ TABLE III: CLINICAL SYMPTOMS RECORDED } \\
\hline Observed symptoms & Frequency $(\mathrm{n}=68)$ \\
\hline Fever & 51 \\
Arthralgia & 45 \\
Fatigue & 43 \\
Headache & 41 \\
Night sweats & 37 \\
Low back pain & 37 \\
In appetite & 33 \\
Chills & 24 \\
\hline \hline
\end{tabular}

\section{B. Laboratory Results}

A total of 71 serum and 71 vaginal swab samples, from 30 sheep and 41 goats were obtained. From these, a total of 12 samples; 8 serum samples by RBPT and 4 vaginal swab samples by PCR were detected for brucellosis. In addition, $7 / 14(50 \%)$ households were found positive for animal brucellosis using the same tests.

\section{Serological results}

From the 71 serum samples, 6 goats and 2 sheep in total 8 (11.1\%) were found positive by RBPT (Table IV).

\section{PCR and duplex PCR}

From the 71 swab samples from sheep and goats, $4(6 \%)$ from goats were found positive by general PCR applying genus specific primers B4 and B5, while all sheep were found negative. Subsequently, these samples were identified $\mathrm{Br}$. melitensis by the applied duplex PCR method (Table IV). The PCR assay was able to detect 2 samples that were obtained in less than 1 week post abortion, 1 sample in less than 2 weeks post abortion and 1sample in less than 1 week post parturition. In addition, the comparison between PCR and RBPT showed that $3 / 4$ PCR positive animals were RBPT negative (sero-negative).

TABLE IV: ANIMAL SAMPLES LABORATORY RESULT

\begin{tabular}{cccc}
\hline \hline \multirow{2}{*}{$\begin{array}{c}\text { Applied } \\
\text { techniques }\end{array}$} & Result & \multicolumn{2}{c}{ Number of samples $(\mathrm{n}=71)$} \\
\cline { 3 - 4 } & & Sheep $(\mathrm{n}=30)$ & Goat $(\mathrm{n}=41)$ \\
\hline RBPT & Positive & $2(6.6 \%)$ & $6(14.6 \%)$ \\
& Negative & 28 & 35 \\
PCR & Positive & 0 & $4(6 \%)$ \\
& Negative & 30 & 37 \\
Duplex PCR & Br. melitensis & 0 & $4(6 \%)$ \\
& Br. abortus & 0 & 0 \\
\hline \hline
\end{tabular}

\section{DISCUSSION}

Previous sero-prevalence studies in the country have confirmed brucellosis endemicity in domesticated animals including cattle, sheep, goats, and camels as well as occupationally exposed humans [8]-[10]. However, identification for commonly occurring brucella species has not been considered before. In addition, brucella infection is a frequently reported zoonotic disease as well as acquiring more attention as the trend is suspected increasing over time in the country (Ministry of Health and Ministry of Agriculture, Eritrea unpublished data). The present study successfully identified $\mathrm{Br}$. melitensis from goat vaginal swab samples using combinatorial PCR. Similarly, laboratory techniques explained in this study can be utilized for molecular diagnosis and species identification of brucellosis.

Bacterial isolation using culture and molecular methods based on PCR tests are used for direct diagnosis of brucella active infection. As well as indirect serological diagnostic tests are also applied for the detection of anti-brucella antibodies in serum samples [1]. The presence of antibrucella antibodies suggests exposure to brucella spp., but it does not indicate which brucella species induced production of those antibodies [1]. DNA detection by polymerase chain reaction (PCR) is commonly utilized tests for the diagnosis of active brucellosis infection in animals and humans and for typing of brucella spp. and biovars. Several methods have been developed and the best validated methods are based on the detection of specific sequences, such as $16 \mathrm{~s}-23 \mathrm{~s}$ genes, omp 2 gene, IS711 insertion sequences and bcsp 31 gene [1], [15]. In this study, Serological Rose Bengal plate test (RBPT) in human cases, whereas both RBPT and molecular PCR test in animals were utilized. The RBPT detection rate in sheep and goats $(11 \%)$ is found low compared to [16], found $32 \%$ sero- prevalence from female sheep and goats using RBPT and ELISA. While higher than Omer et al., 2000 found individual prevalence $4.3 \%$ in goats and $1.4 \%$ in sheep [10]. The applied brucella genes specific PCR was using bcsp 31 gene primers and the duplex (combinatorial) PCR according to Mirnejadet al [17], modifying the original protocol by Bricker and Halling [14]. This protocol is found valuable for specifically identifying B. abortus and B. melitensis, cause of severe zoonotic diseases, using vaginal swab samples. The PCR techniques detected $4(6 \%)$ out of 71 vaginal swab samples from goats, while all sheep swab samples were negative. Similar results in Ethiopia by Tekle et al. [18] indicated 3 out of 27 positivity using combined culture isolation and Bruce ladder multiplex PCR assay in goat vaginal swab. Moreover, in Egypt Ashraf et al., 2019 shows higher detection 10/18 does and 4/25 ewe vaginal swab samples applying similar methods [19]. The possible reason for such variation may be because of low number of infected animals encountered at the time of study. Moreover, from the 4 PCR positive animals, only one was seropositive. This may be related with the time of sampling and age of infection. Serological diagnosis is considered unreliable during the period 2-3 weeks before and after abortion or calving for newly infected animals [2], while PCR gives timely and confirmative results. Therefore, these animals could be newly infected and still not developed detectable antibody titter.

The identification of brucella species is very important for epidemiological surveillance (to know the species and/or biovars diversity) and investigation of outbreaks (to know the source of infection) [20], [21]. The detection of Br. melitensis in goats in the present study suggests the supposed additional risk to increased incidence of human brucellosis. $B$. melitensis is the most common species of brucella in human 
illnesses, with some estimates suggesting cause for $70 \%$ of all infections [22]. The findings of the current study support the finding by Cilli nearly 70 years ago, isolated Brucella melitensis from a local cheese in Agordat (western low land) of Eritrea [10]. Hence, the study observes significance of $\mathrm{Br}$. melitensis and consideration for control programs intervention in the described areas.

Brucellosis is a serious occupational hazard for people professionally exposed to animals such as dairy farm workers and owners, farmers, pastoralists, veterinarians, inseminators, and butchers [23], [24]. In this study, $75 \%$ of the cases were agro pastoralists; lead a mixed crop-livestock system where goats, sheep, cows, donkeys and mainly work oxen with some cows are kept. Brucella has transient stay in yoghurt and sour milk, consequently considered to pose fewer hazards for brucella transmission to humans [24]. In contrast, the significance of yoghurt is shown in the present study, as $40 \%$ of brucella cases had history of yoghurt consumption. Whereas this needs further studies based on a representative sample size for conclusive results.

This study is able to investigate brucella species in goats and probably cause of severe human brucellosis, but it has its own short comings. First it is based on non - probability purposive sampling since the results and findings are not conclusive. Though molecular detection of $\mathrm{Br}$. melitensis suggest the significance of the specie, gives better understanding if detected from animals and in contact humans. Henceforth, further molecular, and epidemiological studies are required to understand the status of infection and to draw rewarding control and prevention strategies.

\section{ACKNOWLEDGMENT}

The authors would like to thank, Director of National Animal and Plant Health laboratory Mr. Efrem Ghebremeskel for his endorsement of this study. As well as Regional Veterinary Officer Mr. Brhane Tekle, and Subzone Veterinarian Mr. Misgna Habtetsion for their support in sample collection and questionnaire interview. Also special thanks to Mr. Hawaz Weldu and Abraham Debru for assisting in developing and designing the study concepts.

\section{ETHICAL CLEARANCE}

Ministry of Health ethical review committee in humans has provided ethical clearance for undertaking the study.

\section{CONFLICT OF INTERESTS}

Authors declared that they have no conflict of interests.

\section{REFERENCES}

[1] Godfroid J, Nielsen K, Saegerman C: Diagnosis of brucellosis in livestock and wildlife. Croatian medical journal, 51(4):296-305.

[2] Radostits OM, Gay C, Hinchcliff KW, Constable PD: A textbook of the diseases of cattle, horses, sheep, pigs and goats. Veterinary medicine 2007, 10:2045-2050.
[3] Godfroid J, Cloeckaert A, Liautard J-P, Kohler S, Fretin D, Walravens K, Garin-Bastuji B, Letesson J-J: From the discovery of the Malta fever's agent to the discovery of a marine mammal reservoir, brucellosis has continuously been a re-emerging zoonosis. Veterinary research 2005, 36(3):313-326.

[4] Xavier M, Paixão T, Poester F, Lage A, Santos R: Pathological, immunohistochemical and bacteriological study of tissues and milk of cows and fetuses experimentally infected with Brucella abortus. Journal of comparative pathology 2009, 140(2-3):149-157.

[5] Dean AS, Crump L, Greter H, Hattendorf J, Schelling E, Zinsstag J: Clinical manifestations of human brucellosis: a systematic review and meta-analysis. PLoS Negl Trop Dis 2012, 6(12):e1929.

[6] Yu WL, Nielsen K: Review of detection of Brucella spp. by polymerase chain reaction. Croatian medical journal 2010, 51(4):306-313.

[7] Baddour MM, Alkhalifa DH: Evaluation of three polymerase chain reaction techniques for detection of Brucella DNA in peripheral human blood. Canadian journal of microbiology 2008, 54(5):352-357.

[8] Scacchia M, Di Provvido A, Ippoliti C, Kefle U, Sebhatu TT, D'Angelo A, De Massis F: Prevalence of brucellosis in dairy cattle from the main dairy farming regions of Eritrea. Onderstepoort Journal of Veterinary Research 2013, 80(1):00-00.

[9] Omer M, Assefaw T, Skjerve E, Tekleghiorghis T, Woldehiwet Z: Prevalence of antibodies to Brucella spp. and risk factors related to high-risk occupational groups in Eritrea. Epidemiology \& Infection 2002, 129(1):85-91.

[10] Omer M, Skjerve E, Holstad G, Woldehiwet Z, Macmillan A: Prevalence of antibodies to Brucella spp. in cattle, sheep, goats, horses and camels in the State of Eritrea; influence of husbandry systems. Epidemiology \& Infection 2000, 125(2):447-453.

[11] Bricker BJ: PCR as a diagnostic tool for brucellosis. Veterinary microbiology 2002, 90(1-4):435-446.

[12] Alton GG, Jones LM, Angus R, Verger J: Techniques for the brucellosis laboratory: Institut National de la recherche Agronomique (INRA); 1988.

[13] Baily G, Krahn J, Drasar B, Stoker N: Detection of Brucella melitensis and Brucella abortus by DNA amplification. Tropical Medicine \& International Health 1992, 95(4):271-275.

[14] Bricker BJ, Halling SM: Differentiation of Brucella abortus bv. 1, 2 , and 4, Brucella melitensis, Brucella ovis, and Brucella suis bv. 1 by PCR. Journal of clinical microbiology 1994, 32(11):2660-2666.

[15] Nagati S, Hassan SK: Diagnosis of Brucella infection in sheep and goat and evaluation of the associated practices in animal contacts. Am J Infect Dis Microbiol 2016, 4(5):95-101.

[16] Alhamada A, Habib I, Barnes A, Robertson I: Risk factors associated with brucella seropositivity in sheep and goats in Duhok Province, Iraq. Veterinary sciences 2017, 4(4):65.

[17] Mirnejad R, Doust RH, Kachuei R, Mortazavi SM, Khoobdel M, Ahamadi A: Simultaneous detection and differentiates of Brucella abortus and Brucella melitensis by combinatorial PCR. Asian pacific journal of tropical medicine 2012, 5(1):24-28.

[18] Tekle M, Legesse M, Edao BM, Ameni G, Mamo G: Isolation and identification of Brucella melitensis using bacteriological and molecular tools from aborted goats in the Afar region of north-eastern Ethiopia. BMC microbiology 2019, 19(1):1-6.

[19] 19. Abdeltwab AA, El-hofy F, Ramadan ES, Refaat S: Diagnostic verification of Brucella species among aborted small ruminants and incontact persons in Minia governorate. Benha Veterinary Medical Journal 2019, 36(2):66-76.

[20] 20. Al Dahouk S, Le Flèche P, Nöckler K, Jacques I, Grayon M, Scholz HC, Tomaso H, Vergnaud G, Neubauer H: Evaluation of Brucella MLVA typing for human brucellosis. Journal of microbiological methods 2007, 69(1):137-145.

[21] Marianelli C, Graziani C, Santangelo C, Xibilia MT, Imbriani A, Amato R, Neri D, Cuccia M, Rinnone S, Di Marco V: Molecular epidemiological and antibiotic susceptibility characterization of Brucella isolates from humans in Sicily, Italy. Journal of Clinical Microbiology 2007, 45(9):2923-2928.

[22] Brucellosis: Brucella [http://www.cfsph.iastate.edu/DiseaseInfo/factsheets.php.].

[23] Galinska EM, Zagórski J: Brucellosis in humans-etiology, diagnostics, clinical forms. Annals of agricultural and environmental medicine 2013, 20(2).

[24] Corbel MJ: Brucellosis in humans and animals: World Health Organization; 2006. 